\title{
New Protein Footprinting: Fast Photochemical lodination Combined with Top-Down and Bottom-Up Mass Spectrometry
}

\author{
Jiawei Chen, Weidong Cui, Daryl Giblin, Michael L. Gross
}

Department of Chemistry, Washington University, One Brookings Drive, St. Louis, MO 63130, USA

\begin{abstract}
We report a new approach for the fast photochemical oxidation of proteins (FPOP) whereby iodine species are used as the modifying reagent. We generate the radicals by photolysis of iodobenzoic acid at $248 \mathrm{~nm}$; the putative iodine radical then rapidly modifies the target protein. This iodine-radical labeling is sensitive, tunable, and site-specific, modifying only histidine and tyrosine residues in contrast to $\mathrm{OH}$ radicals that modify 14 amino-acid side chains. We iodinated myoglobin $(\mathrm{Mb})$ and apomyoglobin $(\mathrm{aMb})$ in their native states and analyzed the outcome by both top-down and bottom-up proteomic strategies. Top-down sequencing selects a certain level (addition of one I, two l's) of modification and determines the major components produced in the modification reaction, whereas bottom-up reveals details for each modification site. Tyr146 is found to be modified for aMb but less so for Mb. His82, His93, and His97 are at least 10 times more modified for $\mathrm{aMb}$ than for $\mathrm{Mb}$, in agreement with NMR studies. For carbonic anhydrase and its apo form, there are no significant differences of the modification extents, indicating their similarity in conformation and providing a control for this approach. For lispro insulin, insulinEDTA, and insulin complexed with zinc, iodination yields are sensitive to differences in insulin oligomerization state. The iodine radical labeling is a promising addition to protein footprinting methods, offering higher specificity and lower reactivity than $\cdot \mathrm{OH}$ and $\mathrm{SO}_{4}^{-}{ }^{-}$, two other radicals already employed in FPOP.
\end{abstract}

Key words: Fast Photochemical Oxidation of Proteins, Protein footprinting, lodination, Myoglobin, Carbonic Anhydrase, Insulin, Top-down sequencing

\section{Introduction}

$\mathrm{M}$ ass spectrometry (MS) approaches using chemical probes are becoming a powerful process for characterizing protein structure. Typical chemical probes include hydrogen-deuterium exchange (H/DX) [1, 2], hydroxyl radical footprinting [3-6], specific chemical modifications of one or two residues [7-9], and cross-linking [10]. As the

Electronic supplementary material The online version of this article (doi:10.1007/s13361-012-0403-1) contains supplementary material, which is available to authorized users.

Correspondence to: Michael L. Gross; e-mail: mgross@wustl.edu most widely used probe for protein structure, H/DX interrogates the hydrogen bonding of backbone amides, whereas the more recently developed hydroxyl-radical oxidation probes the solvent accessibility of various but not all amino-acid side chains.

We developed the FPOP method so that exposed aminoacid residues can be irreversibly and covalently labeled in a relatively simple apparatus by oxidation with hydroxyl radicals produced by photolysis of hydrogen peroxide [4, 11]. The modified residues can be detected and quantified by an approach using trypsin proteolysis followed by LC/MS/ MS analysis (a standard approach in proteomics). Fourteen of 20 amino acids can be modified by hydroxyl radicals for the purpose of footprinting, potentially covering nearly $70 \%$ 
of the sequence of a typical protein [12, 13]. Given that FPOP occurs on a time scale faster than most protein conformational changes [14], it is suitable for both steadystate studies and time-resolved investigations [15, 16]. Recently, we reported that the sulfate radical anion $\left(\cdot \mathrm{OSO}_{3}{ }^{-}\right)$can also be used as an FPOP reagent [17]. This development demonstrates that the scope of FPOP can be increased by using other reactive species including various radicals and possibly carbenes.

In this paper, we describe a new FPOP-based footprinting method using the iodine species produced by laser photolysis to label proteins in a more specific way than $\mathrm{OH}$ radicals. It is well known that iodine atoms can be incorporated enzymatically or non-enzymatically mainly into tyrosine residues of proteins, forming iodotyrosines [18-20]. Some histidines can also be iodinated to an extent depending on the experimental conditions and the structure of the protein [21]. The iodination strategy was previously used for labeling proteins in protein-metabolism studies, radioimmunoassay [18], and protein-structure determination [22-25]. Recently, Ly and Julian [26] utilized the photodissociation of the carbon-iodine bond in iodo-tyrosinecontaining protein to generate a residue-specific radical site for protein cleavage in the gas phase. Although numerous studies focus on protein iodination, none have applied FPOP or any equivalent fast labeling via photo dissociation of an organic iodide (here 4-iodobenzoic acid). Given that the iodine is the least reactive halogen, we anticipate that, unlike $\mathrm{OH}$ radicals, a more specific modification platform will result. In contrast, chlorine and bromine species, which could also be produced by photolysis, react with water promptly to produce hydroxyl radicals, and they were not investigated here.

The traditional MS strategy of locating modification sites and quantifying the fraction of modified sites is bottom-up sequencing [27]. In this approach, both the modified and unmodified proteins are proteolyzed in separate experiments. A liquid-phase chromatographic separation of the resulting peptides followed by MS analysis locates the sites of modification. This approach provides reliable identification of the protein and its modified "siblings" but suffers the risk of peptide losses during digestion and analysis, possibly forfeiting vital information.

More recently, top-down sequencing is emerging as a way to characterize an intact protein and determine its posttranslational modifications (PTMs) [28-30]. With recently developed MS/MS techniques of electron-transfer dissociation (ETD) [31] and electron-capture dissociation (ECD) [32], the top-down approach has become more efficient and gives better sequence coverage and more tolerance towards labile PTMs. Moreover, top-down sequencing informs us whether a modified amino acid has been produced for various labeled states of the protein (e.g., for singly modified, doubly modified. . .). Given the more specific reactivity of iodine species and their higher mass compared to $\mathrm{OH}$, we expect that proteins labeled with $\cdot \mathrm{I}$ are more suitable for top-down analysis than are $\mathrm{OH}$-modified proteins.

In this work, we demonstrate that FPOP-based iodination footprints proteins by modifying solvent-accessible histidine and tyrosine residues. We located the modifications and quantified them by both a top-down approach, which isolates and characterizes the intact mono-iodinated protein, for example, and a bottom-up approach, which identifies the iodinated residues after sample footprinting and quantifies each of them. On the basis of molecular orbital calculations, we make tentative proposal on the iodination mechanism. To our knowledge, this is the first example of iodination being used on the FPOP platform.

\section{Materials and Methods}

\section{Chemicals and Proteins}

Equine skeletal myoglobin, apo-myoglobin, carbonic anhydrase II from bovine erythrocytes, human insulin, 4iodobenzoic acid, proteomics grade trypsin, ethylene diamine tetra-acetic acid (EDTA), zinc chloride, phosphatebuffered saline (PBS, $\mathrm{pH}=7.4$ ), trifluoroacetic acid, 1,10phenanthroline, and ammonium bicarbonate were purchased from Sigma-Aldrich Chemical Company (St. Louis, MO, USA). Lispro was donated by Dr. Stephen Bayne of Novo Nordisk, Denmark. Acetonitrile was obtained from Honeywell Burdick and Jackson (Muskegon, WI, USA). Purified water $(18 \mathrm{M} \Omega)$ was obtained from an in-house Milli-Q Synthesis system (Millipore, Billerica, MA, USA). All chemicals were used without further purification. Apocarbonic anhydrase was prepared by using dialysis of the native protein against $0.1 \mathrm{M}$ sodium acetate, $\mathrm{pH}$ 5.0, containing $2 \times 10^{-3} \mathrm{M} \mathrm{1,10-phenanthroline} \mathrm{at} 4{ }^{\circ} \mathrm{C}$ for $7 \mathrm{~d}$ followed by the removal of the chelating agent by buffer exchange against PBS buffer [33]. Both apo- and holo-states were confirmed by native MS analysis. Insulin-EDTA and insulin-zinc stock solutions were prepared by incubating $0.1 \mathrm{mM}$ insulin with $0.1 \mathrm{mM}$ EDTA and $0.05 \mathrm{mM}$ zinc chloride, respectively. Depletion of zinc ions by EDTA likely caused dissociation of insulin hexamers to dimers, and the addition of zinc ions enhanced the formation of hexamers. The concentrations of all the protein stock solutions were determined by UV absorption $\left(1.55 \times 10^{4} \mathrm{M}^{-1} \mathrm{~cm}^{-1}\right.$ for myoglobin and apo-myoglobin, $5.22 \times 10^{4} \mathrm{M}^{-1} \mathrm{~cm}^{-1}$ for carbonic anhydrase, $5.7 \times 10^{3} \mathrm{M}^{-1} \mathrm{~cm}^{-1}$ for insulin and lispro, all at $280 \mathrm{~nm})$ [34].

\section{Photochemical Protein Iodination}

Each $50 \mu \mathrm{L}$ sample was prepared in PBS $(10 \mathrm{mM}$ phosphate buffer, $138 \mathrm{mM} \mathrm{NaCl}, 2.7 \mathrm{mM} \mathrm{KCl}, \mathrm{pH} 7.4$ at $25^{\circ} \mathrm{C}$ ), with a final protein concentration of $10 \mu \mathrm{M}$. Histidine was chosen as the radical scavenger, and it was added to a final concentration of $0.5 \mathrm{mM}$. An iodobenzoic acid solution was added to a final concentration of $50 \mu \mathrm{M}$, just prior to 
FPOP. The experimental setup and procedure for photolysis were described previously [4]. To ensure that the protein was not "double-shot" $[4,14]$, laser frequency and sample flow rate were adjusted to exclude $15 \%$ of the flowing protein solution from irradiation. The sample solution following irradiation was collected in a centrifuge tube and purified by $\mathrm{C} 18$ Ziptip (Millipore Corporation, Billerica, MA, USA) solid-phase extraction. Proteins were eluted from the Ziptip with $10 \mu \mathrm{L} 50 \%$ acetonitrile and $0.1 \%$ trifluoroacetic acid. Each sample interrogation was conducted in triplicate. Control samples of each set were treated following the same procedure except no laser irradiation was employed.

\section{Electron-Capture Dissociation (ECD) of Iodinated $\mathrm{Mb}$ and $\mathrm{aMb}$}

Global analysis and ECD of iodinated $\mathrm{Mb}$ and $\mathrm{aMb}$ were performed in the positive-ion mode of a Bruker SolariXTM 12 T FT-ICR mass spectrometer (Bruker Daltonics, Bremen, Germany). Direct infusion of protein samples after purification was carried out by pumping at flow rate of $100 \mathrm{~nL} / \mathrm{min}$ with a Harvard Apparatus syringe pump (Instech Laboratories, Inc., Plymouth Meeting, PA, USA). The samples, at an estimated final concentration of $5 \mu \mathrm{M}$, were sprayed at $800 \mathrm{~V}$ into the mass spectrometer via a nanospray emitter (360 $\mu \mathrm{m}$ o.d., $150 \mu \mathrm{m}$ i.d.; Polymicro Technologies, Phoenix, AZ, USA), which was pulled in-house on Polymicro silica tubing by a P2000 laser puller (Sutter Instrument Co., Novato, CA, USA). Mass spectra were recorded at 60,000 mass resolving power (at $\mathrm{m} / \mathrm{z}=1000$ ) with ion accumulation times of $0.001 \mathrm{~s}$ in the ion source, $0.5 \mathrm{~s}$ in the collision/accumulation cell for full spectra, and $2 \mathrm{~s}$ in the collision/accumulation cell for ECD of isolated ions. The argon pressure in the collision/accumulation cell was $5.8 \times 10^{-6} \mathrm{mbar}$; the pressure of the ICR trap region held within the core of the superconducting magnet was $1.4 \times 10^{-9} \mathrm{mbar}$. The trapping voltages of the infinity ICR cell were $0.7 \mathrm{~V}$ on the front plate and $0.8 \mathrm{~V}$ on the back plate. Excitation was $25 \%$ of full power. To perform ECD on mono-iodinated species of both $\mathrm{aMb}$ and $\mathrm{Mb}$, an ion of $\mathrm{m} / \mathrm{z} 1068$ corresponding to $\left[{ }^{*} \mathrm{M}+16 \mathrm{H}\right]^{+16}$, was isolated with a window of $7 \mathrm{Da}$ by the front-end quadrupole. ECD parameters were $1.6 \mathrm{~A}$ to heat the hollow cathode dispenser, $10 \mathrm{~V}$ on the grid, $-0.6 \mathrm{~V}$ for electron extraction, and $60 \mathrm{~ms}$ of extraction length, with slight adjustments of the latter two to optimize the ECD fragmentation of each protein. Up to 200 scans were averaged with $1 \mathrm{M}$ data points for each scan. Ubiquitin was used for calibration.

\section{Proteolysis and LC/MS/MS Analysis}

Triplicate protein samples were dried under vacuum in a SpeedVac and then dissolved in $100 \mathrm{mM}$ ammonium bicarbonate buffer. Trypsin solution $(1 \mathrm{mg} / \mathrm{mL}$ in $1 \mathrm{mM}$ $\mathrm{HCl}$ ) was prepared, and $0.4 \mu \mathrm{L}$ was added to each sample.
Samples were incubated at $37^{\circ} \mathrm{C}$ for $8 \mathrm{~h}$. An aliquot $(5 \mu \mathrm{L})$ of sample was loaded onto a custom-built silica capillary column packed with $\mathrm{C} 18$ reversed-phase material (Magic, $5 \mu \mathrm{m}, 300 \AA$; Michrom, Auburn, CA, USA). The HPLC gradient was from $2 \%$ Solvent B (97 \% acetonitrile, $3 \%$ water, $0.1 \%$ formic acid) and $98 \%$ Solvent A (97\% water, $3 \%$ acetonitrile, $0.1 \%$ formic acid) to $50 \%$ Solvent B over $50 \mathrm{~min}$, then to $85 \%$ Solvent B for $5 \mathrm{~min}$ at a flow rate of $260 \mathrm{~nL} / \mathrm{min}$ followed by a $5 \mathrm{~min}$ re-equilibration step. The solution was sprayed directly from the column into the LTQOrbitrap mass spectrometer (Thermo Fisher, Waltham, MA, USA) by using a PicoView PV-500 nanospray source (New Objective, Woburn, MA, USA). A full mass spectrum of eluting peptides was recorded at high mass resolving power $(100,000$ for ions of $m / z 400)$ while MS/MS experiments on the six most abundant ions from the eluent were performed in the LTQ at a normalized collision energy of $35 \%$ of the maximum, with a $2 \mathrm{Da}$ isolation width and wide-band activation. Ions submitted to MS/MS were placed in a dynamic exclusion list for $8 \mathrm{~s}$.

\section{Data Analysis}

The protein mass spectra from top-down sequencing were analyzed with the Bruker DataAnalysis tool. ECD fragments were assigned with the help of Bruker BioTool 3.2 software. Quantification was done by dividing the sum of intensities of the peaks corresponding to modified and unmodified protein, assuming comparable charging and ionization efficiencies. For the LC/MS/MS data analysis, a general Mascot search and a sequential error-tolerant search as the first step were necessary not only to evaluate sequence coverage but also to provide valuable information of the possible modified sites. Then a list was created manually for each protein; the list contained the $\mathrm{m} / \mathrm{z}$ of all charge states of the identified peptides, both unmodified and modified. Peptides were validated by manual inspection of their accurate mass, retention time, and production (MS/MS) spectra. Ion chromatograms were extracted according to the peptide list, and the peak areas were measured. Modification yields for all the associated peptides were expressed as the ratio of the modified peptide to the sum of both modified and unmodified peptide.

\section{Circular Dichroism Experiments}

CD spectra were obtained at $4{ }^{\circ} \mathrm{C}$ using a J-815 CD spectrometer (JASCO Analytical Instruments, Tokyo, Japan). All experiments were done after placing the protein in a PBS buffer. Spectra were measured with a sample cell having a $0.1 \mathrm{~cm}$ path length, at a scan resolution of $0.2 \mathrm{~nm}$, and a scan rate of $50 \mathrm{~nm} / \mathrm{min}$.

\section{Theoretical Calculations}

Theoretical calculations were performed to characterize the potential-energy surface (PES) associated with halide radical 
attachment and fixation. As surrogates for tyrosine and histidine, we chose $p$-cresol and 4-methylimidazole, respectively, both of which retain the same side-chain functionality of the amino acid and require less computational overhead. We focused the calculations on processes that generate 2iodo-4-methylphenol in analogy to 3-iodotyrosine and 2iodo-4-methylimidazole in analogy to 2-iodohistidine. Iodination of both amino acids occurred in the footprinting done here, but the precise location of the I label was not determined. Structures of precursors and intermediates were explored by MMFF molecular mechanics, and associated transition states were explored by using the PM3 semiempirical [35, 36] algorithm (Spartan for Linux ver. 02; Wavefunction, Inc.). Minima and transition states were optimized by DFT (Density Function Theory) method M06 for improved accuracy [37] and by using the LanL2DZ basis set, both in the Gaussian 09 suite [38] (Gaussian Inc., Wallingford CT, USA) and were verified by vibrationalfrequency analysis. Connection of transition states to minima were examined by reaction-path calculations. Calculated energies with thermal-energy corrections were applied and reported in $\mathrm{kJ} / \mathrm{mol}$ as enthalpies of reaction from either $p$-cresol or 4-methylimidazole [39].

\section{Results and Discussion}

\section{Footprinting Proteins by Iodination}

To develop iodination footprinting, we need a source of reactive iodine species that react with amino-acid side chains of proteins. We chose iodobenzoic acid as the radical source, and submitted it to photodissociation with the $\mathrm{KrF}$ laser. The photodissociation mechanism of 4-iodobenzoic acid is expected to be similar to that of aryl halides such as iodobenzene [40]. The cleavage of the $\mathrm{C}-\mathrm{I}$ bond in aryl iodides is an indirect process consisting of an excitation in the range $250 \pm 30 \mathrm{~nm}$, promoting the molecule to the $\left(\pi, \pi^{*}\right)$ state. An internal conversion to the repulsive $\left(n, \sigma^{*}\right)$ state occurs before the C-I bond rapidly breaks [40-42]. In the absence of other reactive species, the iodine radicals and carboxy phenyl radicals from iodobenzoic acid are then expected to undergo recombination reactions [43]. Although these precedents are dated, they nevertheless are consistent with the observations made here. Although we are able to establish that the amino-acid residues of a protein react productively with the iodine species generated by the laser photolysis, this reaction had not yet been previously characterized. We also demonstrated, as described later in this paper, that both histidine and tyrosine can be modified, depending on the solvent environment of these residues and the ratio of the protein concentration to that of the iodine species that were formed by laser photolysis.

To explore how proteins are iodinated in this footprinting experiment, one can design a variety of experimental approaches including those involving model peptides. These experiments are time-consuming and may not be conclusive even after considerable effort. Because our principal goal in this first study is to introduce iodine footprinting of proteins and to determine whether the reactions are useful in footprinting, we studied three proteins. In lieu of a detailed experimental study on mechanism, we turned instead to molecular orbital calculations to probe how the putative iodine radical would react with His and Tyr residues, as is observed here (see Materials and Methods).

The results indicate that the iodine radical itself does not initially make a formal covalent bond to a ring carbon and disrupt the aromatic $\pi$-electron system (Scheme 1). Instead, the radical forms a loose complex with the $\pi$ system, bonding weakly at a carbon of the aromatic ring with carbon-iodine distance greater than $3 \AA$. Molecular oxygen attack at an adjacent or a conjugated carbon induces the covalent attachment of the iodine radical to the ring. Abstraction of the hydrogen atom on the carbon of the $\mathrm{C}-\mathrm{I}$ bond by a $\mathrm{C}-\mathrm{O}-\mathrm{O}^{\circ}$ functionality followed by elimination of the $\mathrm{HO}_{2} \cdot$ leaves the iodine substituted on the ring, in analogy to the proposed mechanism for hydroxyl radical substitution on an aromatic ring in pulsed radiolysis [3]. Note that the relative enthalpies of the intermediates indicate that the processes are overall exothermic, and abstractions of hydrogen atoms are likely the rate-limiting steps with moderate energetic barriers.

If the mechanism is correct, reactions with other aromatic amino-acid side chains would be expected, and yet none are observed. Thus, mechanism at this point is highly speculative and must await a systematic study.

The main products of traditional iodination of histidine are 2-iodohistidine, 2,5-di-iodohistidine and 1,2,5-tri-iodohistidine, whereas 3,5-di-iodotyrosine is the major product for tyrosine iodination [44]. Previous studies suggest that the rate of iodination of histidine is 30-100 times slower than that of tyrosine [44]. To avoid over-labeling that would induce conformational changes in the protein, we used free histidine amino acid as a scavenger by adding it to the protein solution to control radical-exposure time. The basis for this approach is histidine's reactivity to consume iodine radicals at moderate rate and yet not completely quench the radicals before they react with the protein. We monitored the amount of scavenger versus the level of modification and found an appropriate concentration of $0.5 \mathrm{mM}$ for the experiments. A previous pulse-radiolysis study [45] reports a second-order rate constant for the reaction of I with proteins in the range of $3 \times 10^{10}$ to $3 \times 10^{11} \mathrm{M}^{-1} \mathrm{~s}-{ }^{1}$, which is similar to the range observed for the hydroxyl radical in various pulse radiolysis experiments [46]. Thus, we expect that all I. would have reacted within microseconds of their creation [45]. Admittedly, the lifetime of the radicals remains a subject for future research.

As for other radicals used in FPOP, the radical lifetime would be short in the presence of the scavenger, such that the protein is modified before structural changes are induced by over-labeling. Under controlled experimental conditions, we found no modified histidine in the protein other than 

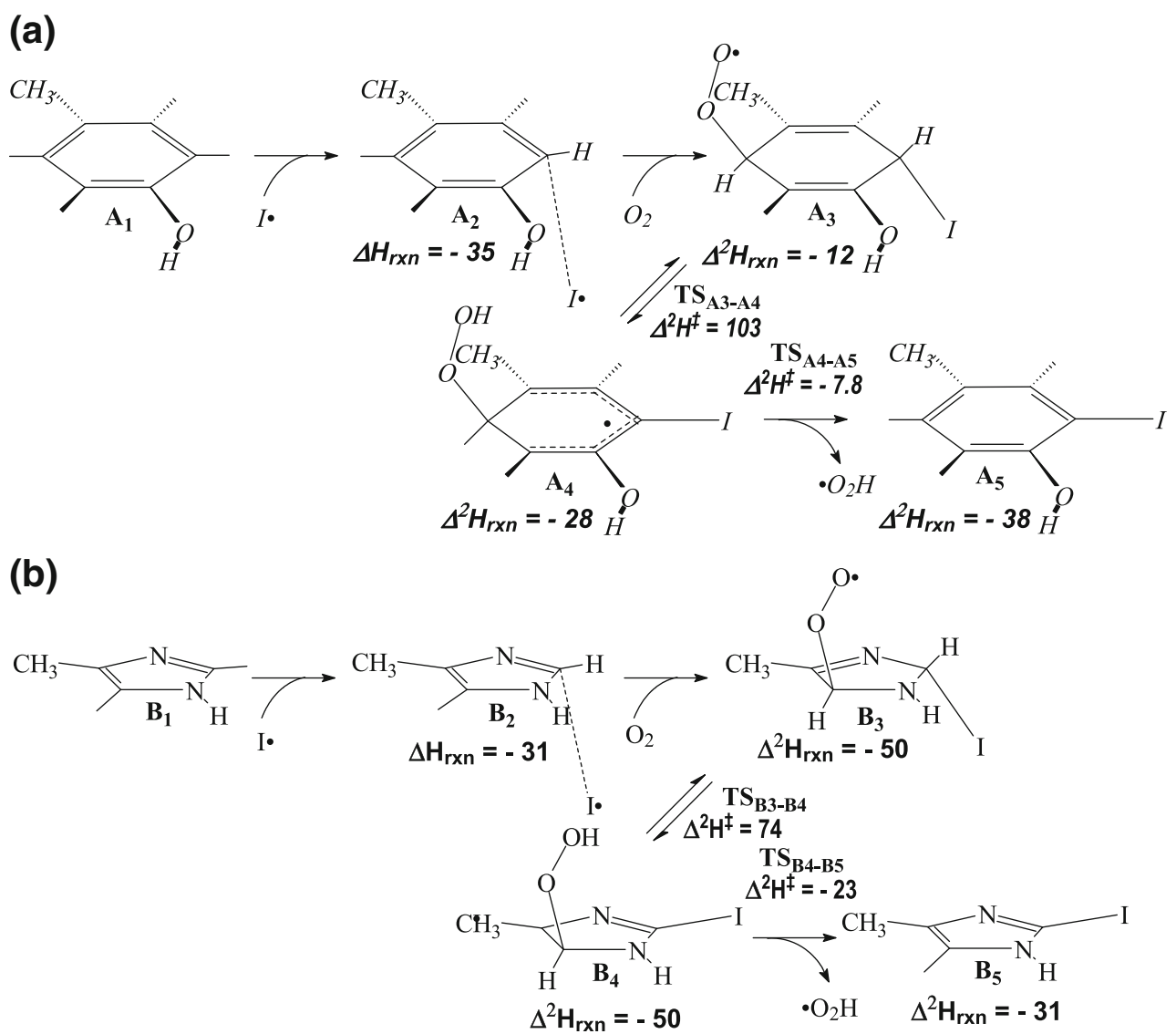

Scheme 1. Proposed mechanisms of formation of iodo products from an iodine radical atom and $p$-cresol (a) and 4methylimidazole (b). Enthalpies are reported in $\mathrm{kJ} / \mathrm{mol}$ as enthalpies of reaction from either $p$-cresol or 4-methylimidazole for (a) and (b), respectively

mono-iodohistidine, whereas we detected by using MS both mono-iodotyrosine and di-iodotyrosine in the protein. The CD spectra of proteins before and after iodination do not change, providing further evidence that iodination under the conditions used here does not over label the protein (the spectra are nearly identical [see Figure S-1 in Supplemental Data]). Therefore, iodination under our experimental conditions does not alter significantly the proteins' secondary structure although we do not have any firm data on the lifetime of the putative radical.

\section{Analyzing the Global Results by Mass Spectrometry: Myoglobin}

Upon modification by reaction with the I species, the mass of the protein increases in integral multiples of $125.904 \mathrm{Da}$ corresponding to $[\mathrm{M}+n(\mathrm{I}-\mathrm{H})](n=1,2 \ldots$ where $n=0$ corresponds to no modification); the single modification ( $n=$ 1) is the most prevalent in the case of $\mathrm{Mb}$ and apoMb. $\mathrm{Mb}$ is a 153 amino-acid protein existing in a highly folded and compact structure with eight $\mapsto$-helical secondary structures that wrap around a central pocket containing the heme group. ApoMb, lacking the heme group between helices $\mathrm{E}$ and $\mathrm{F}$, is the intermediate in biosynthesis of Mb. Structural characterization by NMR indicates that although most of the $\mathrm{aMb}$ polypeptide chain adopts a well-defined structure, some of the structural elements including the EF loop, the F helix, the FG loop, the first few residues of the $\mathrm{G}$ helix, and the $\mathrm{C}$ terminal end of the $\mathrm{H}$ helix, fluctuate between a native conformation and less structured conformations [47]. Limited proteolysis experiments also demonstrated that helix $\mathrm{F}$ is highly flexible or largely disrupted in apoMb [48].

Global MS measurements of modified $\mathrm{Mb}$ and apoMb that were iodinated under the same experimental conditions (Figure 1) clearly show a difference in the extent of iodination. Mono-iodinated species are present at $38 \%$ of the unmodified species for $\mathrm{Mb}$ (Figure 1a), but they increase to $130 \%$ for apoMb (Figure 1b). Furthermore, there is no detectable tri-iodinated $\mathrm{Mb}$, but tri-iodinated apoMb is clearly visible, indicating that heme removal leads to a looser protein conformation that has an increased number of solvent-exposed histidine and tyrosine residues.

No peaks other than those corresponding to the protein and the iodinated protein were observed above $3 \%$ relative intensity of the base peak. This poses another question not answered in this first study: namely, what is the fate of the carboxyphenyl radical formed along with the putative I. Perhaps these and other radical species are quenched before 

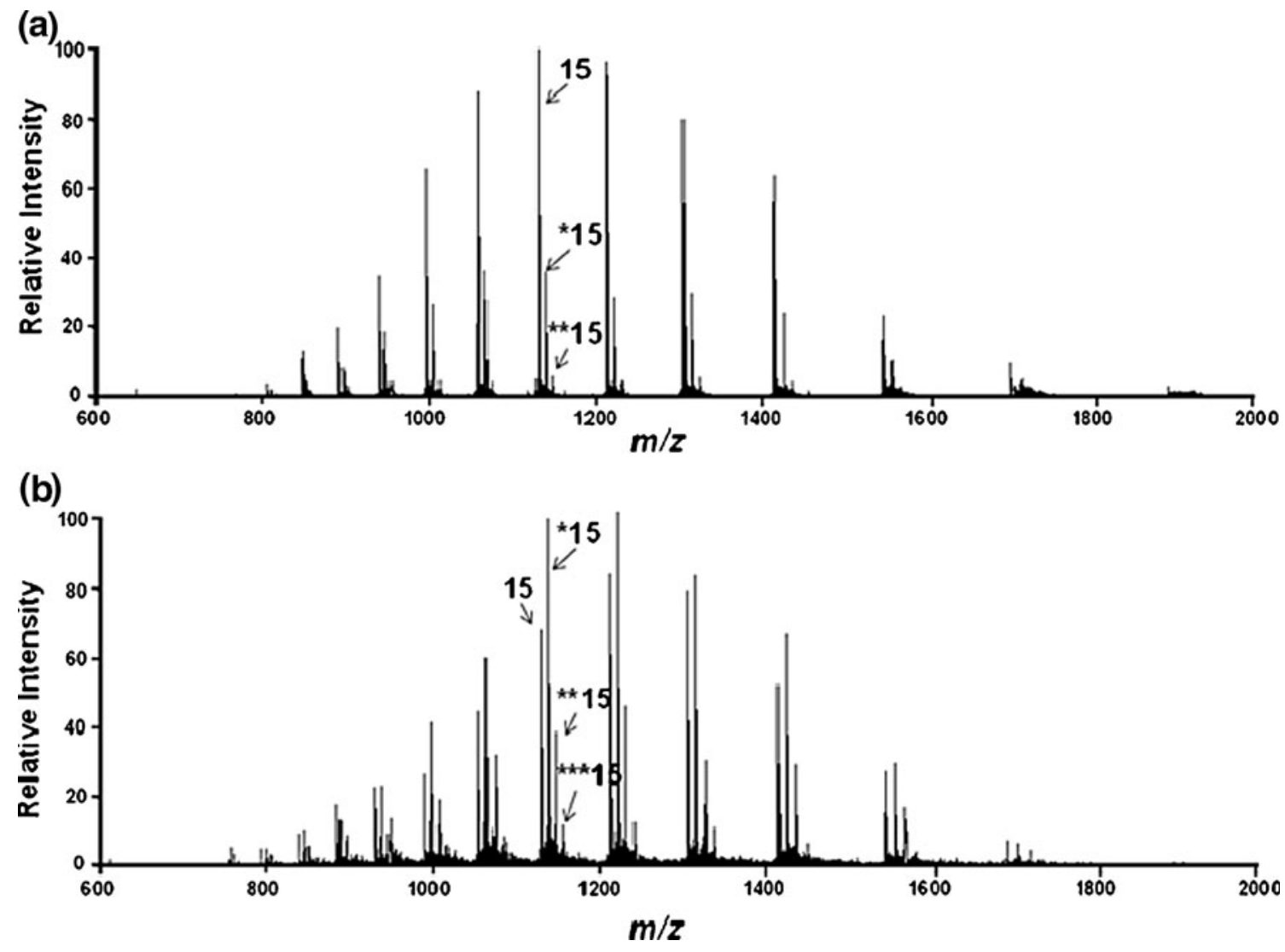

Figure. 1. (a) Full ESI mass spectrum of iodinated myoglobin (Mb). (b) Full ESI mass spectrum of iodinated apomyoglobin (aMb). The unmodified, mono-, di-, and tri-iodinated species of the 15th charge state are indicated by the number of stars

they can react with the protein. These other radicals may remove $\mathrm{H} \cdot$ to form carbon-centered radicals that are quenched by subsequent reaction with I. Nevertheless, iodination appears to be a sensitive probe for structural change when combined with MS analysis, and we expect that results at the amino-acid level should be informative.

\section{Locating Sites of Modification: Top-down Analysis}

There are precedents for top-down analysis of iodinated proteins. Iniesta et al. [49] reported the first top-down experiment to locate a single iodinated tyrosine of myoglobin that was produced by electrosynthesis. Recently, Sun et al. [50] applied radical direct dissociation (RDD) and ECD to locate sites of iodination in several proteins.

Top-down sequencing may be conducted either by selecting all the states of protein, unmodified and modified, or by isolating one particular modification state (e.g., monoiodinated). To identify the location(s) of the site(s) of modification and to avoid interference of the unmodified protein, we chose to isolate the protein possessing one modified site. In this experiment, $\left[{ }^{*} \mathrm{Mb}+16 \mathrm{H}\right]^{+16}$ of $\mathrm{m} / \mathrm{z}$ 1068 , representing a protein bearing a single iodine, when isolated and subjected to ECD, gave a series of $c$ and $z$ ions for identification and quantification (Figure 2). Given that the proteins either without modification or with more than one modification were excluded prior to ECD, we should be able to determine the distribution of iodine in the mono-iodinated species. Consider fragmentation at a site that can yield a $c(z)$ ion containing only one modifiable site (i.e., a histidine or tyrosine). If the histidine or tyrosine is fractionally modified, two $c$ ions will form, one carrying the modifications and one not. The fractional modification at that site is the yield of the modified $c(z)$ ion divided by the sum of the modified and unmodified. This assumes that the presence of iodine on the side chain does not affect the fragmentation yields.

For apoMb, we measured the yield of iodinated $z_{8}{ }^{+}$ion to be $26 \%$ of the total of modified and unmodified $z_{8}^{+}$, indicating that among all the mono-iodinated species, $26 \%$ of them are iodinated at Y146. This amino-acid residue is the only one that can be modified in the region represented by the fragment. There is no modified $z_{8}{ }^{+}$for $\mathrm{Mb}$, however, indicating that Y146 is now protected from iodination. Determining that no modification occurred in a region of the protein is even simpler. For example, there is no detectable modified $c_{59}{ }^{4+}$ ion for both apoMb and $\mathrm{Mb}$, indicating that $\mathrm{H} 24$, H36, and H48, the three modifiable sites in this fragment, are highly protected and do not react with the reactive I species.

Conclusions become more difficult for larger ions that contain more than one modifiable site. Consider two $z$ ions, 
$\mathrm{aMb}$

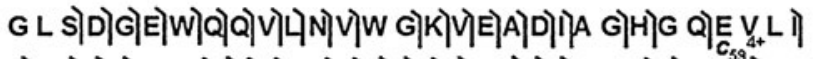

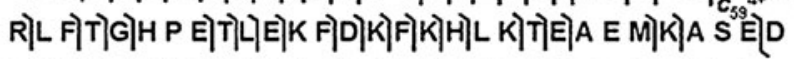
LK|KH G|T]V\}V 니TA L G|G ILK)K|K GHHEAELKPLA

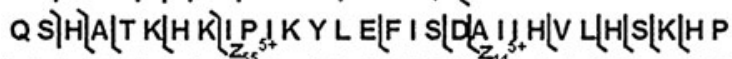

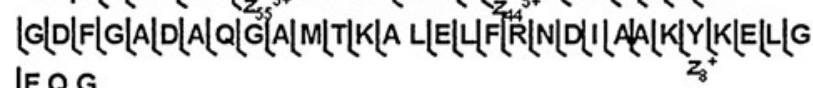
LFQG
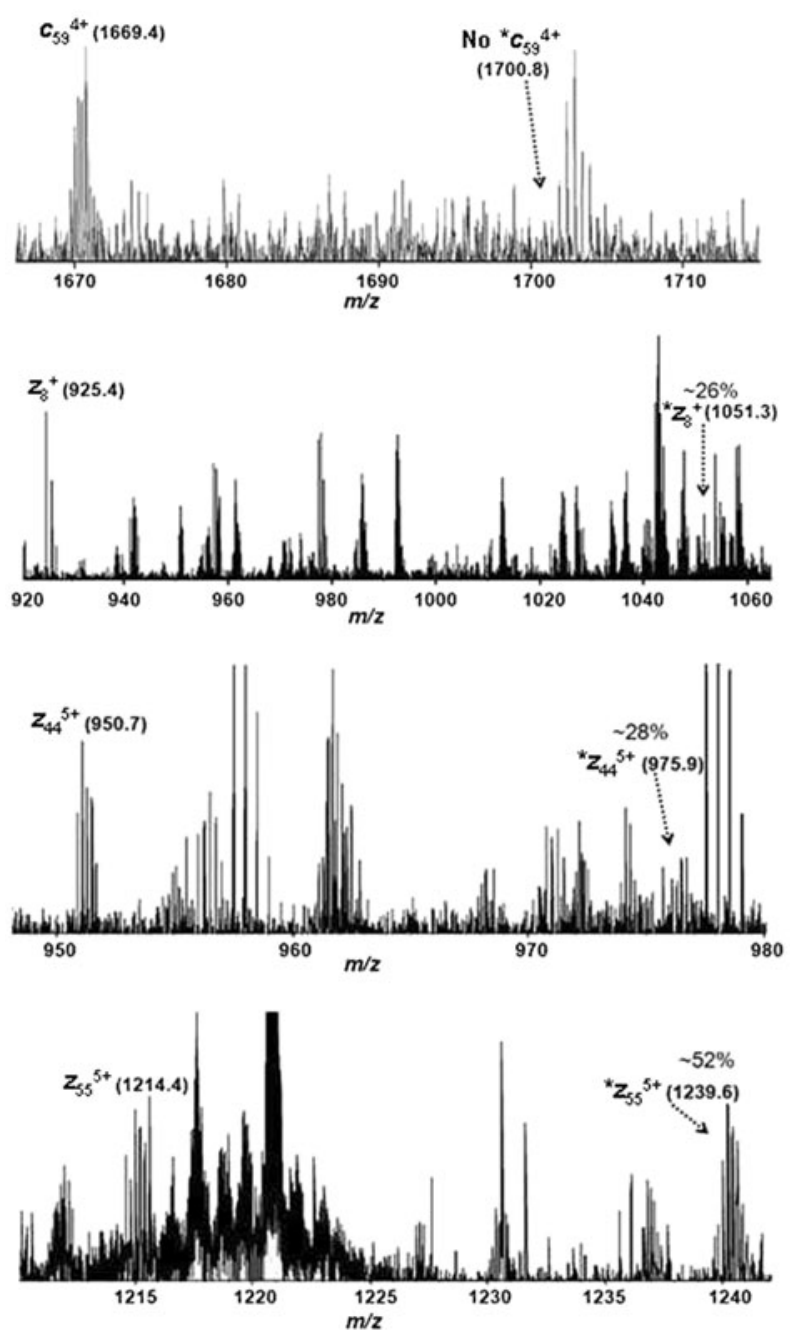

$\mathrm{Mb}$

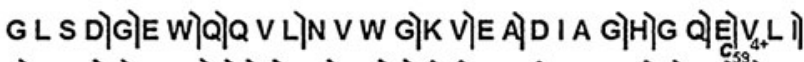

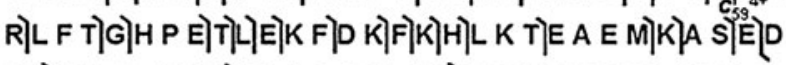
LK)KHGTVV LاTTALGGILKK)KGHHEAELKPLA

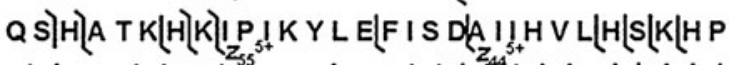

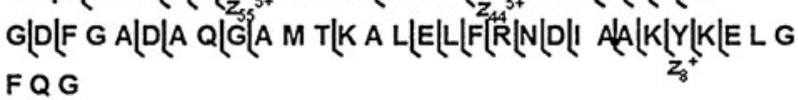
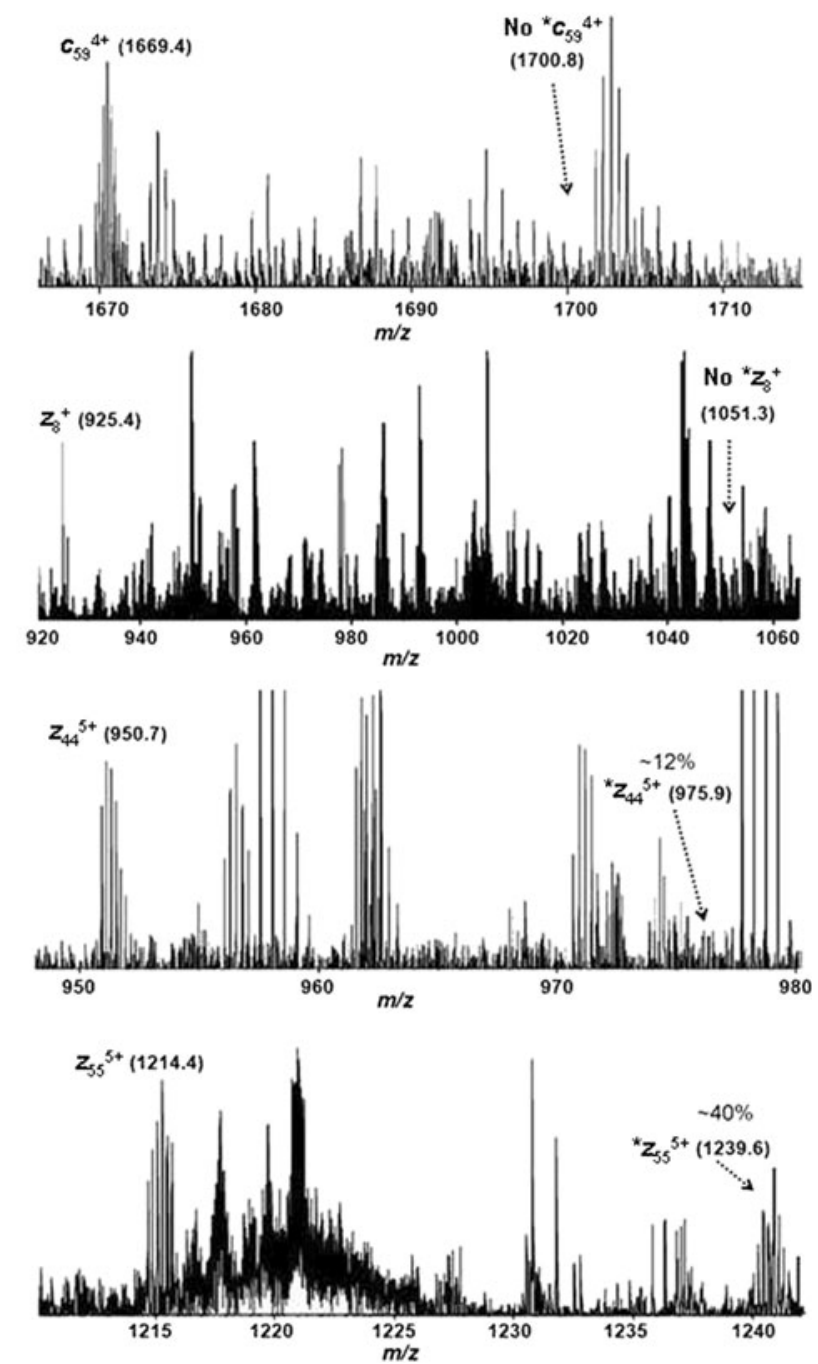

Figure 2. Sequence coverage and the zoomed-in ECD spectra of $\left[{ }^{\star} \mathrm{aMb}+16 \mathrm{H}\right]^{16+}$ and $\left[{ }^{\star} \mathrm{Mb}+16 \mathrm{H}\right]^{16+}$

the smaller containing $\mathrm{x}$ modifiable sites and the larger containing $\mathrm{x}+1$ modifiable sites. This is the case for $\mathrm{z}_{44}{ }^{5+}$ and $\mathrm{z}_{55}{ }^{5+}$. The former contains $\mathrm{Y} 146$ and the latter Y146 and Y103. The percent modified $\mathrm{z}_{44}{ }^{5+}$ and $\mathrm{z}_{55}{ }^{5+}$ are $28 \%$ and $52 \%$, respectively, for $\mathrm{aMb}$, allowing us to surmise that $24 \%(52 \%-28 \%)$ of the mono-iodinated proteins are iodinated at Y103 because it is the only modifiable site in the sequence between $\mathrm{z}_{44}{ }^{5+}$ and $\mathrm{z}_{55}{ }^{5+}$. For $\mathrm{Mb}$, the percentages are lower at $12 \%$ and $40 \%$, but the difference in Y103 iodination is $28 \%$, slightly larger than that for $\mathrm{aMb}$. Thus, Y103 has comparable solvent accessibility for both
apoMb and $\mathrm{Mb}$, whereas $\mathrm{Y} 146$ is exposed in apoMb but protected in $\mathrm{Mb}$. This would be difficult to do with $\mathrm{OH}$ radical footprinting because $\cdot \mathrm{OH}$ is so reactive and modifies many sites.

The remainder of the iodination occurs mostly in the middle of the sequence of $\mathrm{Mb}$. Although we could obtain reasonable sequence coverage in the top-down sequencing, the modification yields at the residue level were difficult to determine for those amino-acid residues that incurred minor amounts of modification or were located in the middle of an unfragmented protein sequence. For these cases, top-down 
sequencing does not allow assignment of 11 histidine residues, some of which are located close to each other in the middle of the protein sequence. We calculated the percentage of mono-iodinated $\mathrm{z}_{55}{ }^{5+}$ in $\mathrm{aMb}$ and $\mathrm{Mb}$ to be $52 \%$ and $40 \%$, respectively, as described above, leaving the remaining $48 \%$ and $60 \%$ not assigned to any particular sites. Thus, we look to bottom-up sequencing for confirmation.

\section{Locating Sites of Modification: Bottom-up Sequencing}

To complete the assignments and aid the evaluation of the top-down data, we applied bottom-up sequencing to both $\mathrm{Mb}$ and apoMb. We relied primarily on the accurate masses of each tryptic peptide and those of its modified "siblings" to obtain extracted-ion chromatograms. For peptides containing more than one histidine/tyrosine site, high chromatographic efficiency and informative MS/MS data can locate the modification. To calculate the fraction modified, we summed in the numerator the signal intensities corresponding to all peptides having a modification at a given residue and summed in the denominator all the intensities of detected peptides that contain the residue; this summation includes all charge states of a peptide. As an example, the extracted ion chromatograms of peptide 80-96, which contains three histidines (Figure 3), show that three peptides formed from digestion of the monoiodinated $\mathrm{aMb}$ elute sequentially at 22.8, 23.0, and $23.5 \mathrm{~min}$. On the basis of product-ion spectra (MS/MS), we conclude that the three comparably abundant eluates contain iodinated H93, H81, and H82, respectively. Turning to $\mathrm{Mb}$, we find that the abundance ratios for these three components change, and now H93 and H82 were modified to a small extent.

A comparison of overall calculated residue-level modifications of apoMb and $\mathrm{Mb}$ (Figure 4) shows that residues $\mathrm{H} 82, \mathrm{H} 93$, and $\mathrm{H} 97$ are modified more than $2 \%$ in apoMb but less than $0.2 \%$ in $\mathrm{Mb}$, indicating a significant difference between the apo- and holo-proteins at the sites containing these residues. Residues H24, H36, H48, H64, H113, H116, and $\mathrm{H} 119$ are modified at less than $1.0 \%$ in both the apo and holo proteins. Among those histidines, $\mathrm{H} 48$ and $\mathrm{H} 113$ are iodinated to a greater extent for $\mathrm{Mb}$ than for apoMb. Residues H82, H93, and H97 are modified in excess of $1.0 \%$ for apoMb, significantly greater than for $\mathrm{Mb}$. Residue H81 is modified most extensively among all histidines in $\mathrm{Mb}$; the yield is $1.5 \%$, slightly smaller than for apoMb $(2.0 \%)$. Although it is likely that the modified and unmodified peptides have different ionization efficiencies that might compromise the quantification, any bias is suffered by all the peptides, and, thus, the bias does not affect the quantitative trends we observe and the conclusions we draw when we compare two states (e.g., apo and holo). Indeed, the trends reflect structural differences between apo and holo states.

\section{Comparing MS and NMR Results}

Our results agree well with previous findings on the structures of apo- and holo-myoglobin studied by NMR [51]. Those results indicate that helix $\mathrm{F}$, which contains residues $\mathrm{H} 82, \mathrm{H} 93$, and $\mathrm{H} 97$, is not formed for apoMb but is well formed for $\mathrm{Mb}$. The same conclusion can be drawn from our experiment; there is a significant extent of iodination on $\mathrm{H} 82$, H93, and $\mathrm{H} 97$ in apoMb, but the labeling is considerably diminished for the $\mathrm{Mb}$. We conclude that $\mathrm{I}$. footprinting is highly sensitive to structure and leads to the same conclusions as those from NMR.

Furthermore, there is other footprinting evidence in accord with the NMR results. We find that H81 is highly iodinated in both apoMb and $\mathrm{Mb}$, whereas $\mathrm{H} 82$, the adjoining amino acid, responds differently to the apo or holo state of the protein. The NMR shows little signal for H81 for both states, indicating that H81exists as part of a random coil regardless of the state.
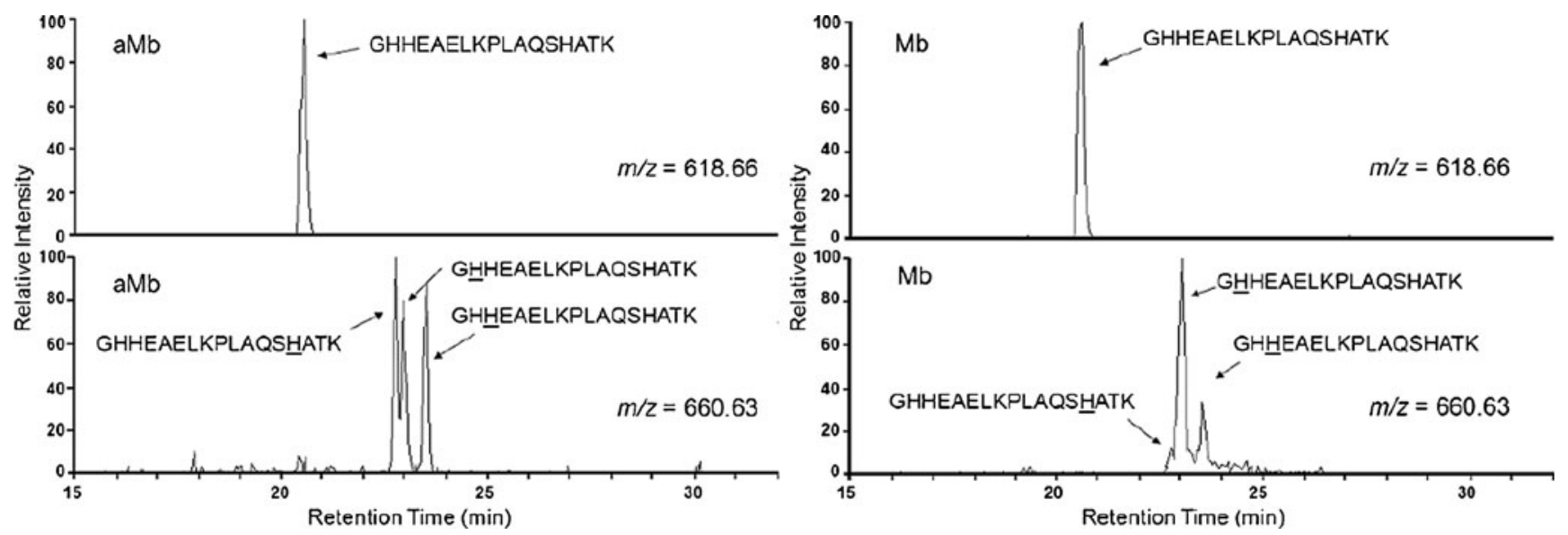

Figure 3. Extracted ion chromatograms of doubly charged peptide 80-96 of aMb (top left) and Mb (top right), monoiodinated peptide 80-96 of aMb (bottom left) and aMb (bottom right). The assigned modification sites are underlined 


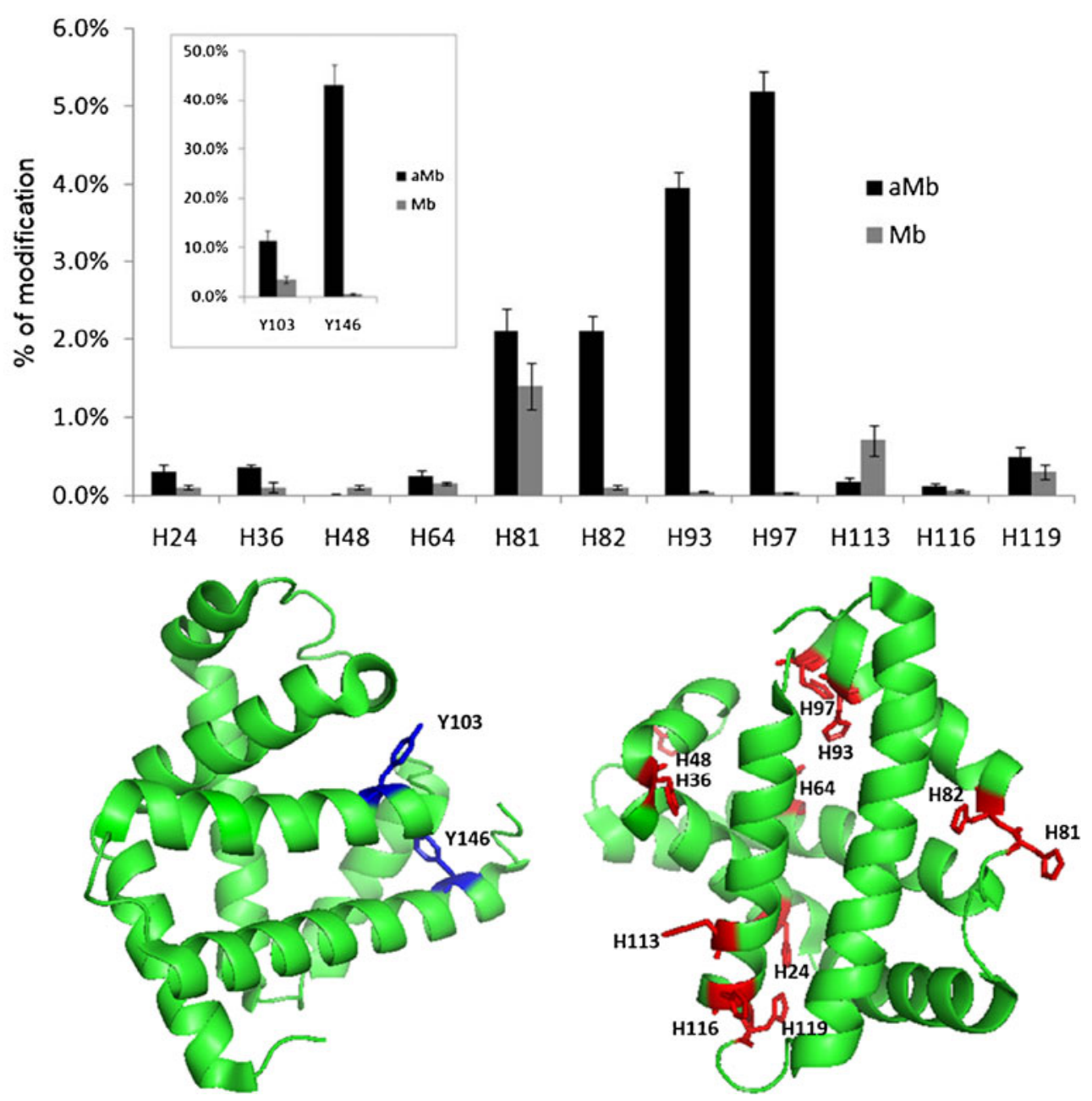

Figure 4. Plot of the yield of iodinated histidine and tyrosine residues in $\mathrm{aMb}$ and $\mathrm{Mb}$, analyzed by bottom up strategy (top). Tyrosine and histidine sites mapped in a crystal structure of myoglobin (bottom, PDB ID: 1WLA)

It is relatively common to produce di-iodinated tyrosines in this experiment. In bottom-up data analysis, we took into account every iodinated species, no matter how many modifications are on one site, summing all their signal areas to obtain the total abundance of modified peptides even though our focus is singly modified species of all types. For this reason and larger dynamic range of bottom-up sequencing, we find larger numbers of tyrosine modifications in the bottom-up rather than the top-down approach.

\section{Comparing Bottom-up and Top-down}

Bottom-up and top-down strategies are complementary and have different advantages in analyzing differences in protein structures. Bottom-up experiments, despite possible biases in enzymatic cleavage, can determine the modification fractions for each amino acid, down to less than $0.2 \%$. This low level of detection in bottom-up sequencing is an advantage over the top-down approach when studying a protein that is rich in histidine and tyrosine. Top-down sequencing (as shown for $\mathrm{Mb}$ and $\mathrm{apoMb}$ ) provides estimates of where modifications happen most frequently, but it lacks the sensitivity and dynamic range that are available in the bottom-up approach. The top-down approach selects only a given modified state of a protein (we chose only the singly modified) and, thus, excludes those proteins that have undergone two or more modifications. Bottom-up analysis integrates over all modification states of the protein (e.g., mono-iodination, di-iodination). Top-down sequencing can be used to determine the distribution of modifiable sites within a protein state or among different states, and the results can roughly serve to evaluate the modification level in regions where there are several reactive residues. Topdown sequencing also eliminates sample-preparation steps and avoids peptide loss.

\section{Application: Iodination of Apo- and Holo- Carbonic Anhydrase II}

We applied this FPOP-based iodination method to apoand holo-carbonic anhydrase. Carbonic anhydrase is a 
zinc-containing metalloenzyme that catalyzes the hydration of $\mathrm{CO}_{2}$ in solution. The extents of modification at the residue level should be a function of the solvent accessibility of the particular residue, as shown by the protein structure onto which the tyrosine and histidine residues are mapped (Figure 5). The comparison of the modification extent of the same residue between the two states shows no significant difference of the solvent accessibility of apo and holo (Figure 5), examined by $t$ test. This result supports previous conclusions showing that the removal of the zinc causes very little change to the tertiary structure of the protein [52, 53]. This experiment serves as a negative control, and the results support our contention that iodination extents are a measure of conformation and its change between two states.

\section{Application: Iodination of Lispro Insulin, Insulin-EDTA, and the Zinc form of Insulin}

We also submitted lispro insulin, recombinant human insulin-EDTA, and the zinc form of insulin to iodination to test the applicability of this footprinting strategy for mapping the interaction sites in protein oligomers. We chose these systems because human insulin exists as a dimer in the absence of zinc and as a hexamer in the presence of zinc, whereas the lispro isoform is monomeric [54]. Furthermore, there are four tyrosines in each insulin (or lispro) monomer: Y14 and Y19 in the A chain, Y16 and Y26 in the B chain, providing an appropriate number of targets for the footprinting. Under the experimental conditions we chose for FPOP, an insulin-EDTA solution is likely comprised of monomers and dimers, whereas the zinc form of insulin is

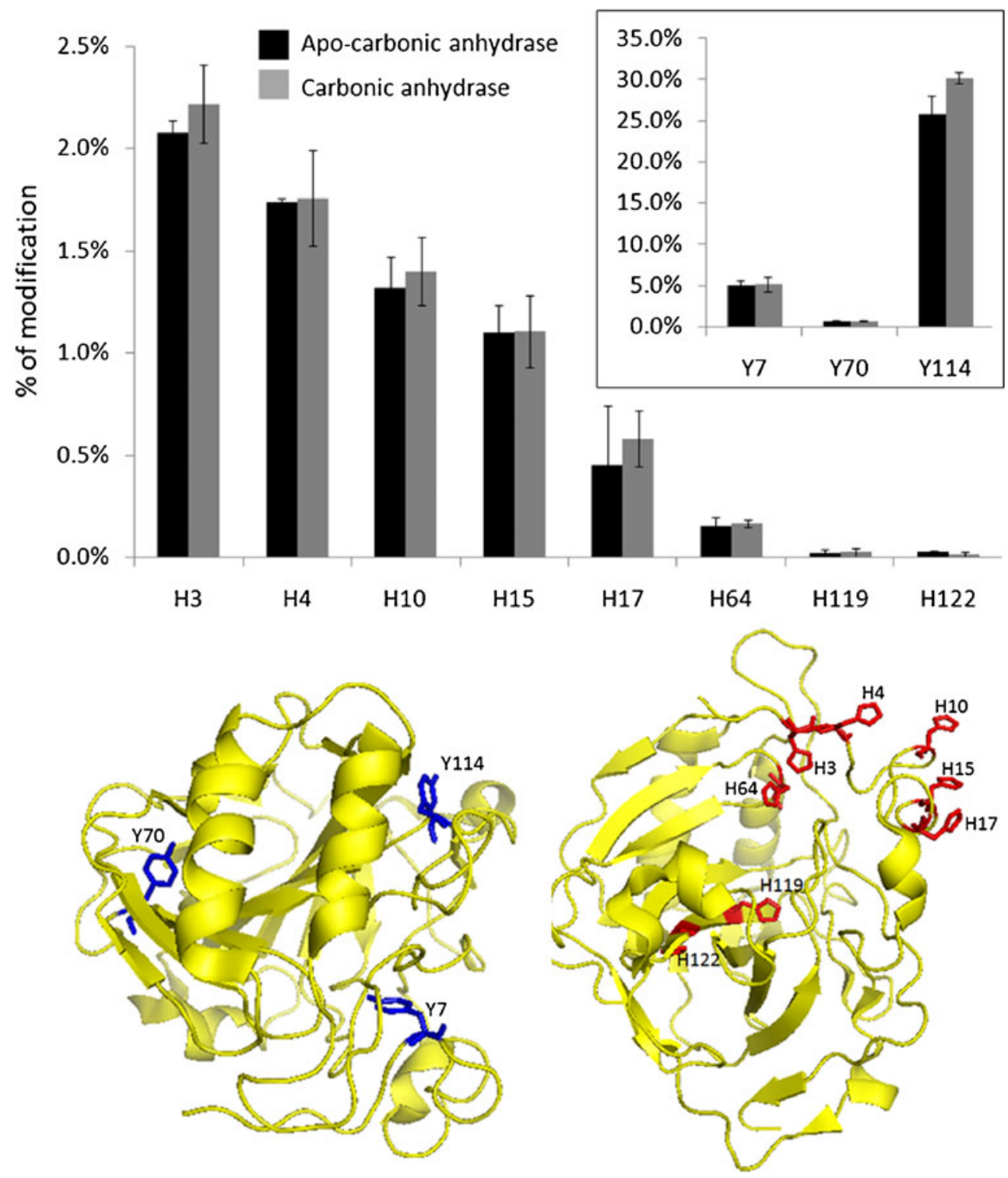

Figure 5. Plot of the yield of iodinated histidine and tyrosine residues in apo- and holo-carbonic anhydrase, analyzed by bottom-up strategy (top). Tyrosine and histidine sites mapped in a crystal structure of carbonic anhydrase (bottom, PDB ID: 2CBA) 
mainly an equilibrated mixture of dimers and hexamers. Lispro, a protein in which proline 28 and lysine 29 of the B chain in human insulin are interchanged, exists mainly as a monomer in solution. As such, it has a more rapid response in diabetes therapy [55].

The iodination yields for lispro, insulin-EDTA, and zinc form of insulin (Figure 6) show that the two tyrosines in the A chain are iodinated to a comparable extent for lispro and human insulin-EDTA. The other two tyrosines (Y16 and Y26) of the B chain, however, are more modified in lispro, consistent with the previous findings that these residues are involved in the dimerization interface of the human form. All tyrosines in the zinc form of insulin are modified to a lower extent than in the other two forms, likely owing to the increased protection that occurs upon the formation of hexamers. Although an ensemble of different oligomeric states is likely sampled in these experiments, the modification differences among them confirm some of the interaction sites involved in oligomerization.

\section{Conclusions}

One outcome of this study is a demonstration of the versatility of the FPOP strategy in its ability to accommodate various reagents. The iodine species produced from photolysis of 4-iodobenzoic acid selectively modifies histidine and tyrosine residues in proteins, and, more importantly, serves as a specific probe for changes in protein conformation
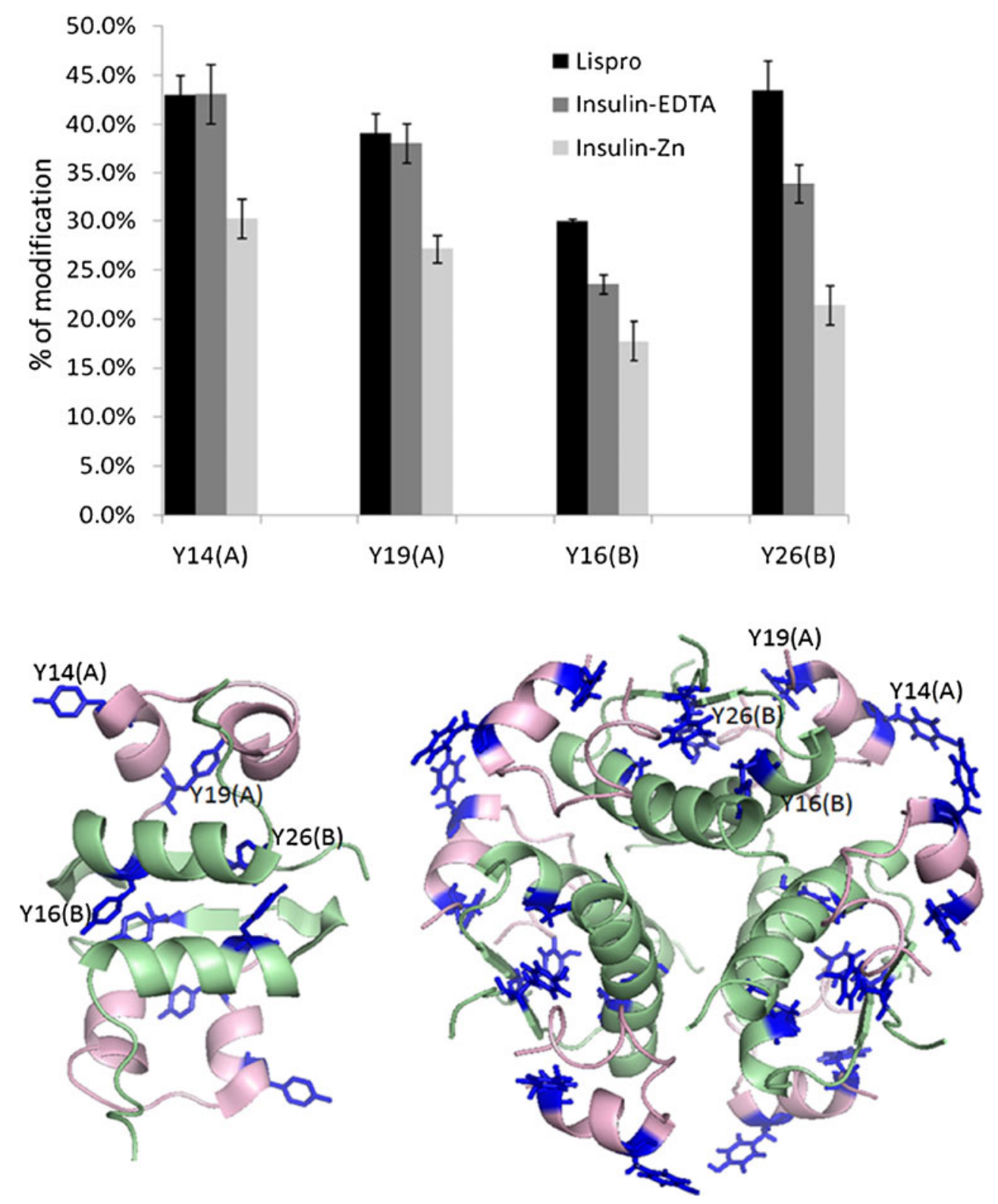

Figure 6. Plot of the yield of iodinated tyrosine residues in lispro, insulin with EDTA and the zinc form of insulin, analyzed by the bottom-up strategy (top). Tyrosine sites mapped in one insulin molecule present in a native dimer structure (bottom left, PDB ID: 1GUJ) and a hexamer structure (bottom right, PDB ID: 1AIO) 
between apo versus holo states and as an indicator of protein oligomerization. The difference in modification extents can be seen in either the global mass spectral data or the peptide and amino-acid residue-level comparisons. The data processing is relatively easy compared with $\cdot \mathrm{OH}$ FPOP owing to the modification specificity for only two amino acids and the larger mass displacement than for oxidative modifications by $\cdot \mathrm{OH}$. Unlike hydrogen peroxide, which gradually oxidizes protein even without photolysis, the precursor for $\cdot I$ does not react with a protein in the absence of laser irradiation; thus, we can be certain that modification is only due to reactions with an iodine species. For this reason, removing the radical-generating reagent following protein modification is not as critical as in -OH FPOP experiments [56]. Unlike other specific footprinting reactions (e.g., acetylation of Lys or addition of $N$-ethylmaleimide to Cys), radical reactions occur rapidly, most likely on a time scale that preempts protein unfolding, providing an advantage for iodination and other radical footprinting processes. Characterizing iodination modification by bottom-up and/or topdown depends largely on the protein sequence and the residues that are of interest. To our knowledge, this is the first example of combining protein footprinting and topdown MS analysis.

In the future, we intend to develop for FPOP more reagents that generate different radicals with different selectivity towards amino acids, affording a protein footprinting "tool box" containing a variety of radicals appropriate for answering different and difficult questions in protein science and proteomics. We also see the opportunity for conducting FPOP in vivo by using reagents such as the iodine precursor used here; reagents of this type may be effectively admitted to cells and serve as a precursor for reactive radicals that would be produced only upon a pulse of laser light. Finally, we are planning studies to investigate in detail the mechanism of the footprinting reaction.

\section{Acknowledgments}

The authors acknowledge support for this work by the NIH (grant P41RR000954, now 8 P41GM103422) and High-End Instrument Program of the NCRR (grant 1 S10 025101) to M.L.G. Additional support was provided by Merck. M.L.G. was a consultant for Merck.

\section{References}

1. Englander, J.J., Del Mar, C., Li, W., Englander, S.W., Kim, J.S., Stranz, D.D., Hamuro, Y., Woods Jr., V.L.: Protein structure change studied by hydrogen-deuterium exchange, functional labeling, and mass spectrometry. Proc. Natl. Acad. Sci. U.S.A 100, 7057-7062 (2003)

2. Kaltashov, I.A., Bobst, C.E., Abzalimov, R.R.: H/D exchange and mass spectrometry in the studies of protein conformation and dynamics: is there a need for a top-down approach? Anal. Chem. 81, 7892-7899 (2009)

3. Xu, G., Chance, M.R.: Hydroxyl radical-mediated modification of proteins as probes for structural proteomics. Chem. Rev. 107, 35143543 (2007)
4. Hambly, D.M., Gross, M.L.: Laser flash photolysis of hydrogen peroxide to oxidize protein solvent-accessible residues on the microsecond timescale. J. Am. Soc. Mass Spectrom. 16, 2057-2063 (2005)

5. Konermann, L., Stocks, B.B., Pan, Y., Tong, X.: Mass spectrometry combined with oxidative labeling for exploring protein structure and folding. Mass Spectrom. Rev. 29, 651-667 (2010)

6. Kiselar, J.G., Chance, M.R.: Future directions of structural mass spectrometry using hydroxyl radical footprinting. J. Mass Spectrom. 45, 1373-1382 (2010)

7. Jha, S.K., Udgaonkar, J.B.: Exploring the cooperativity of the fast folding reaction of a small protein using pulsed thiol labeling and mass spectrometry. J. Biol. Chem. 282, 37479-37491 (2007)

8. Guan, L., Kaback, H.R.: Site-directed alkylation of cysteine to test solvent accessibility of membrane proteins. Nat. Protoc. 2, 2012-2017 (2007)

9. Wen, J., Zhang, H., Gross, M.L., Blankenship, R.E.: Membrane orientation of the FMO antenna protein from Chlorobaculum tepidum as determined by mass spectrometry-based footprinting. Proc. Natl. Acad. Sci. U.S.A. 106, 6134-6139 (2009)

10. Back, J.W., de Jong, L., Muijsers, A.O., de Koster, C.G.: Chemical cross-linking and mass spectrometry for protein structural modeling. $J$. Mol. Biol. 331, 303-313 (2003)

11. Hambly, D.M., Gross, M.L.: Laser flash photochemical oxidation to locate heme binding and conformational change in myoglobin. Int. J. Mass Spectrom. 259, 124-129 (2007)

12. Guozhong Xu, M.R.C.: Radiolytic modification and reactivity of amino acid residues serving as structural probes for protein footprinting. Anal. Chem. 77, 4549-4555 (2005)

13. Xu, G., Chance, M.R.: Radiolytic modification of acidic amino acid residues in peptides: probes for examining protein-protein interactions. Anal. Chem. 76, 1213-1221 (2004)

14. Gau, B.C., Sharp, J.S., Rempel, D.L., Gross, M.L.: Fast photochemical oxidation of protein footprints faster than protein unfolding. Anal. Chem. 81, 6563-6571 (2009)

15. Chen, J., Rempel, D.L., Gross, M.L.: Temperature jump and fast photochemical oxidation probe submillisecond protein folding. J. Am. Chem. Soc. 132, 15502-15504 (2010)

16. Stocks, B.B., Konermann, L.: Structural characterization of short-lived protein unfolding intermediates by laser-induced oxidative labeling and mass spectrometry. Anal. Chem. 81, 20-27 (2009)

17. Gau, B.C., Chen, H., Zhang, Y., Gross, M.L.: Sulfate radical anion as a new reagent for fast photochemical oxidation of proteins. Anal. Chem. 82, 7821-7827 (2010)

18. Morrison, M., Schonbaum, G.R.: Peroxidase-catalyzed halogenation. Annu. Rev. Biochem. 45, 861-888 (1976)

19. Huwiler, M., Burgi, U., Kohler, H.: Mechanism of enzymatic and nonenzymatic tyrosine iodination. Inhibition by excess hydrogen peroxide and/or iodide. Eur. J. Biochem. 147, 469-476 (1985)

20. Taurog, A., Dorris, M.L., Doerge, D.R.: Mechanism of simultaneous iodination and coupling catalyzed by thyroid peroxidase. Arch. Biochem. Biophys. 330, 24-32 (1996)

21. Wolff, J., Covelli, I.: Factors in the iodination of histidine in proteins. Eur. J. Biochem. 9, 371-377 (1969)

22. Kretsinger, R.H.: A crystallographic study of iodinated sperm whale metmyoglobin. J. Mol. Biol. 31, 315-318 (1968)

23. Sigler, P.B.: Iodination of a single tyrosine in crystals of $\mapsto-$ chymotrypsin. Biochemistry 9, 3609-3617 (1970)

24. Ghosh, D., Erman, M., Sawicki, M., Lala, P., Weeks, D.R., Li, N., Pangborn, W., Thiel, D.J., Jornvall, H., Gutierrez, R., Eyzaguirre, J.: Determination of a protein structure by iodination: the structure of iodinated acetylxylan esterase. Acta Crystallogr. D Biol. Crystallogr. 55, 779-784 (1999)

25. Ly, T., Julian, R.R.: Elucidating the tertiary structure of protein ions in vacuo with site specific photoinitiated radical reactions. J. Am. Chem. Soc. 132, 8602-8609 (2010)

26. Ly, T., Julian, R.R.: Residue-specific radical-directed dissociation of whole proteins in the gas phase. J. Am. Chem. Soc. 130, 351-358 (2008)

27. Takamoto, K., Chance, M.R.: Radiolytic protein footprinting with mass spectrometry to probe the structure of macromolecular complexes. Annu. Rev. Biophys. Biomol. Struct. 35, 251-276 (2006)

28. Meng, F., Forbes, A.J., Miller, L.M., Kelleher, N.L.: Detection and localization of protein modifications by high resolution tandem mass spectrometry. Mass Spectrom. Rev. 24, 126-134 (2004) 
29. Pesavento, J.J., Mizzen, C.A., Kelleher, N.L.: Quantitative analysis of modified proteins and their positional isomers by tandem mass spectrometry: human histone H4. Anal. Chem. 78, 4271-4280 (2006)

30. Ge, Y., Rybakova, I.N., Xu, Q., Moss, R.L.: Top-down high-resolution mass spectrometry of cardiac myosin binding protein $\mathrm{C}$ revealed that truncation alters protein phosphorylation state. Proc. Natl. Acad. Sci. U. S.A. 106, 12658-12663 (2009)

31. Syka, J.E., Coon, J.J., Schroeder, M.J., Shabanowitz, J., Hunt, D.F.: Peptide and protein sequence analysis by electron transfer dissociation mass spectrometry. Proc. Natl. Acad. Sci. U.S.A. 101, 9528-9533 (2004)

32. McLafferty, F.W., Horn, D.M., Breuker, K., Ge, Y., Lewis, M.A., Cerda, B., Zubarev, R.A., Carpenter, B.K.: Electron capture dissociation of gaseous multiply charged ions by Fourier-transform ion cyclotron resonance. J. Am. Soc. Mass Spectrom. 12, 245-249 (2001)

33. Lindskog, S., Malmstrom, B.G.: Metal binding and catalytic activity in bovine carbonic anhydrase. J. Biol. Chem. 237, 1129-1137 (1962)

34. Pace, C.N., Vajdos, F., Fee, L., Grimsley, G., Gray, T.: How to measure and predict the molar absorption coefficient of a protein. Protein Sci. 4, 2411-2423 (1995)

35. Stewart, J. J. P.: Optimization of parameters for semiempirical methods. I. Method. J. Comp. Chem. 10 (1989)

36. Stewart, J. J. P.: Optimization of parameters for semiempirical methods. II. Applications. J. Comp. Chem. 10 (1989)

37. Frisch, M.J., Trucks, G.W., Schlegel, H.B., Scuseria, G.E., Robb, M.A., Cheeseman, J.R., Vakrzewski, V.G., Montgomery Jr., J.A., Stratmann, R.E., Burant, J.C., Dapprich, S., Millam, J.M., Daniels, A.D., Kudin, K. N., Strain, M.C., Farkas, O., Tomasi, J., Barone, V., Cossi, M., Cammi, R., Mennucci, B., Pomelli, C., Adamo, C., Clifford, S., Ochterski, J., Petersson, G.A., Ayala, P.Y., Cui, Q., Morokuma, K., Malick, D.K., Rabuck, A.D., Raghavachari, K., Foresman, J.B., Cioslowski, J., Ortiz, J.V., Stefanov, B.B., Liu, G., Liashenko, A., Piskorz, P., Komaromi, I., Gomperts, R., Martin, R.L., Fox, D.J., Keith, T., Al-Laham, M.A., Peng, C.Y., Nanayakkara, A., Gonzalez, C., Challacombe, M., Gill, P. M.W., Johnson, B., Chen, W., Wong, M.W., Andres, J.L., Gonzalez, C., Head-Gordon, M., Replogle, E.S., Pople, J.A.: Gaussian 98, Revision A.6. Gaussian, Inc, Pittsburgh (1998)

38. Frisch, M.J., Trucks, G.W., Schlegel, H.B., Scuseria, G.E., Robb, M.A., Cheeseman, J.R., Montgomery Jr., J.A., Vreven, T., Kudin, K.N., Burant, J.C., Millam, J.M., Iyengar, S.S., Tomasi, J., Barone, V., Mennucci, B., Cossi, M., Scalmani, G., Rega, N., Petersson, A., Nakatsuji, H., Hada, M., Ehara, M., Toyota, K., Fukuda, R., Hasegawa, J., Ishida, M., Nakajima, T., Honda, Y., Kitao, O., Nakai, H., Klene, M., Li, X., Knox, J.E., Hratchian, H.P., Cross, J.B., Adamo, C., Jaramillo, J., Gomperts, R., Stratmann, R.E., Yazyev, O., Austin, A.J., Cammi, R., Pomelli, C., Ochterski, J.W., Ayala, P.Y., Morokuma, K., Voth, G.A., Salvador, P., Dannenberg, J.J., Zakrzewski, V.G., Dapprich, S., Daniels, A.D., Strain, M.C., Farkas, O., Malick, D.K., Rabuck, A.D., Raghavachari, K., Foresman, J.B., Ortiz, J.V., Cui, Q., Baboul, A.G., Clifford, S., Cioslowski, J., Stefanov, B.B., Liu, G., Liashenko, A., Piskorz, P., Komaromi, I., Martin, R.L., Fox, D.J., Keith, T., Al-Laham, M.A., Peng, C.Y., Nanayakkara, A., Challacombe, M., Gill, P.M.W., Johnson, B., Chen, W., Wong, M.W., Gonzalez, C., Pople, J.A.: Gaussian 03, Revision C.02. Gaussian, Inc, Wallingford (2004)
39. Scott, A.P., Radom, L.: Harmonic Vibrational Frequencies: an evaluation of Hartree-Fock, Møller-Plesset, Quadratic Configuration Interaction, Density Functional Theory, and Semiempirical Scale Factors. J. Phys. Chem. 100, 16502-16513 (1996)

40. Dzvonik, M., Yang, S., Bersohn, R.: Photodissociation of molecular beams of aryl halides. J. Chem. Phys. 61, 4408-4421 (1974)

41. Kawasaki, M., Lee, S.J., Bersohn, R.: Photodissociation of molecular beams of aryl halides: Translational energy distribution of the fragments. J. Chem. Phys. 66, 2647-2655 (1977)

42. Cheng, P.Y., Zhong, D., Zewail, A.H.: Kinetic-energy, femtosecond resolved reaction dynamics. Modes of dissociation (in iodobenzene) from time-velocity correlations. Chem. Phys. Lett. 237, 399-405 (1995)

43. Furlan, A.: Photodissociation of a surface-active species at a liquid surface: a study by time-of-flight mass spectroscopy. J. Phys. Chem. B 103, 1550-1557 (1999)

44. Li, C.H.: Kinetics of reactions between iodine and histidine. J. Am. Chem. Soc. 66, 225-227 (1944)

45. Quintiliani, M., Shebal, J., Davies, J.V., Ebert, M., Gilbert, C.W.: Reactions of radiation-induced $\mathrm{I}^{*}, \mathrm{I}_{2}^{-}, \mathrm{I}_{3}^{-}$with alcohol dehydrogenase and aldolase. Int. J. Radiat. Biol. 24, 243-255 (1973)

46. Maleknis, S.D., Brenowitz, M., Chance, M.R.: Millisecond radiolytic modification of peptides by synchrotron X-rays identified by mass spectrometry. Anal. Chem. 71, 3965-3973 (1999)

47. Eliezer, D., Wright, P.E.: Is apomyoglobin a molten globule? Structural characterization by NMR. J. Mol. Biol. 263, 531-538 (1996)

48. Picotti, P., Marabotti, A., Negro, A., Musi, V., Spolaore, B., Zambonin, M., Fontana, A.: Modulation of the structural integrity of helix $\mathrm{F}$ in apomyoglobin by single amino acid replacements. Protein Sci. 13, 1572-1585 (2004)

49. Iniesta, J., Cooper, H.J., Marshall, A.G., Heptinstall, J., Walton, D.J., Peterson, I.R.: Specific electrochemical iodination of horse heart myoglobin at tyrosine 103 as determined by Fourier transform ion cyclotron resonance mass spectrometry. Arch. Biochem. Biophys. 474, 1-7 (2008)

50. Sun, Q., Yin, S., Loo, J.A., Julian, R.R.: Radical directed dissociation for facile identification of iodotyrosine residues using electrospray ionization mass spectrometry. Anal. Chem. 82, 3826-3833 (2010)

51. Eliezer, D., Yao, J., Dyson, H.J., Wright, P.: Structural and dynamic characterization of partially folded states of apomyoglobin and implications for protein folding. Nat. Strul. Biol. 18, 148-155 (1998)

52. Brewer, J.M., Spencer, T.E., Ashworth, R.B.: Zinc effect on physical properties of bovine carbonic anhydrase. Biochem. Biophys. Acta 168, 359-361 (1968)

53. Hakansson, K., Carlsson, M., Svensson, L.A., Liljas, A.: Structure of native and apo carbonic anhydrase II and structure of some of its anionligand complexes. J. Mol. Biol. 227, 1192-1204 (1992)

54. Jeffrey, P.D., Coates, J.H.: An equilibrium ultracentrifuge study of the self-association of bovine insulin. Biochemistry 5, 489-498 (1966)

55. Holleman, F., Hoekstra, J.B.: Insulin lispro. N. England J. Med. 337, 176-183 (1997)

56. Hambly, D.M., Gross, M.L.: Cold chemical oxidation of proteins. Anal. Chem. 81, 7235-7242 (2009) 